\title{
Economic benefit analysis of green building based on fuzzy logic and bilateral game model
}

\section{Chen, Zhuolun}

Published in:

Journal of Intelligent and Fuzzy Systems

Link to article, DOI:

10.3233/JIFS-179087

Publication date:

2019

Document Version

Peer reviewed version

Link back to DTU Orbit

Citation (APA):

Chen, Z. (2019). Economic benefit analysis of green building based on fuzzy logic and bilateral game model. Journal of Intelligent and Fuzzy Systems, 37(1), 301-313. https://doi.org/10.3233/JIFS-179087

\section{General rights}

Copyright and moral rights for the publications made accessible in the public portal are retained by the authors and/or other copyright owners and it is a condition of accessing publications that users recognise and abide by the legal requirements associated with these rights.

- Users may download and print one copy of any publication from the public portal for the purpose of private study or research.

- You may not further distribute the material or use it for any profit-making activity or commercial gain

- You may freely distribute the URL identifying the publication in the public portal 


\title{
Economic benefit analysis of green building based on fuzzy logic and bilateral game model
}

\author{
Zhuolun Chen a,b,* \\ a Architecture Design and Research Institute, School of Architecture, South China University of Technology, \\ Guangzhou 510640, Guangzhou, China \\ ${ }^{b}$ Copenhagen Center on Energy Efficiency, Department of management Engineering, Technical University of \\ Denmark, UNEP-DTU Partnership, Copenhagen 2100, Denmark
}

*Corresponding author: Zhuolun Chen, email: arzlchen@scut.edu.cn

\begin{abstract}
Green building is the development of sustainable development concept in architectural field. While the construction industry has brought great benefits to the development of national economy, its high investment, high pollution and inefficient development mode has also produced a huge energy load. Therefore, from the perspective of environmental and economic sustainability, the development of green buildings is particularly important. In this paper, the author makes economic benefit analysis of green building based on fuzzy logic and bilateral game model. By introducing such factors as economic benefits, cognition and government policies, this paper construct an evolutionary game model, which provides a basis for improving the economic benefits of green buildings. The results show that the first factor affecting enterprise decision-making is the incremental profit of green building developers, followed by the government's incentive policy. After the evolution of the market, the final strategic choice will be stabilized to higher economic benefits. Generally speaking, green buildings need to effectively control incremental costs and consider scale benefits. Through management efficiency innovation and policy stimulation, the problems of huge investment cost and long payback period can be solved, so as to improve the economic benefits of green building development.
\end{abstract}

Keywords: Green building, game theory, incentive mechanism, benefit analysis

\section{Introduction}

In January 2015, the Central Economic Work Conference fully explained the characteristics of the "new normal economy". In December the same year, the Central Economic Work Conference proposed to focus on strengthening the structural reform, in the moderate expansion of aggregate demand at the same time, to capacity, to inventory, to leverage, reduce costs, and make short board[1]. Economic development mode from extensive to intensive growth, low efficiency, high pollution shift to high efficiency, low emission development, driven by factor-driven shift to innovation-driven development model [2,3]. The face of supply-side reform of the new normal, China's green building development must take the road of innovation, overall innovation needs of the whole industrial chain innovation[4,5]. However, the development process of green building involves many participants, including government, owners, developers, contractors, suppliers, consumers, the public and other stakeholders, for different subjects to pursue their own interests[6]. Different subjects for the pursuit of their own interests, their behavior choices vary, their behavior will greatly affect the development of green building process. Zheng introduced the value chain theory, and they pointed out that the green building supply chain management is characterized by large scale and long duration[7]. The lack of common benefit basis among the multi - stakeholder involved in the green building, and the lack of effective coopera- 
tion innovation incentive mechanism seriously hampered the development of green building in China[8].

The main contribution of this paper is to makes economic benefit analysis of green building based on fuzzy logic and bilateral game model. By introducing such factors as economic benefits, cognition and government policies, this paper construct an evolutionary game model, which provides a basis for improving the economic benefits of green buildings. The results show that the first factor affecting enterprise decision-making is the incremental profit of green building developers, followed by the government's incentive policy. After the evolution of the market, the final strategic choice will be stabilized to higher economic benefits. Generally speaking, green buildings need to effectively control incremental costs and consider scale benefits.

This paper is organized as follows: The related work is introduced in Section II. Model hypothesis and Green building developer - home buyers evolutionary game analysis is described in Section III. Green Building Developer - Government Evolutionary Game Analysis is presented in Section IV and Construction of Green Building Evaluation System is presented SectionV. Countermeasures and Suggestions in Section VI. Finally, Conclusions are given in Section VII.

\section{Related work}

In the process of promoting green building, incentive is an effective means to improve the performance of the project. Motivation mechanism can be divided into three types: incentive based on cost, monetary and non-monetary incentive, contract and external contract incentive[9]. Revenue incentive is one of the key issues in the project incentive. As a long-term dynamic incentive model, emotional incentive has a lasting incentive and constraint effect on project-oriented organizations[10]. Many scholars use the external theory of economics to analyze the external economy of green building[11,12]. Vyas (2017) analyzed the cost-effectiveness of green building[13]. Asadullah (2016) analyzed the method of building intellectualization[14]. Zuo (2017) Evaluates Green Buildings from the Life Cycle Perspective[15]. MacNaughton (2016) analyses the environmental perception and health of green buildings[16].Jones (2016) analyzed the development of green strategy[17].Tam (2017) Analysis of Life Cycle Cost of Green Building Implementation[18]. In order to solve the problem of "market failure" in green building, the author puts forward the design of incentive mechanism of green building by setting up the market allocation model of green building.

In the incentive mechanism design research, the green building related cooperation between enterprises is to implement the basis of innovation. Cuifang Zhang has studied the quality decision under asymmetric information, quality evaluation decisionmaking, payment transfer decision-making and coordination mechanism of rewards and punishments. Hong-bo WANG according to the theory of incentive mechanism, qualitative analysis is carried out on incentive objectives, incentive objects and incentives of green building, and established the government and the developer community evolutionary game model, proposed that the government should lock the farsighted incentive policy[19]. Jian-gang SHI based on the fairness preference, this paper constructs a crossorganizational two-way incentive model, and analyzes the impact of project effort, fairness preference, payment cost and distribution system on project value increment[20]. Based on the above research results, domestic and foreign scholars do not consider the influence of interaction decision among the stakeholders in the coordination of interests of green building propulsion mechanism[21,22,23]. In the selection of incentive subjects, the driving factors of green building promotion mechanism are not clear.

From the supply side perspective, real estate developers in the green building development path by the "economic interests", "emotional awareness", "policy-oriented" three conditions of the constraints. Specifically, the internal factors of green building developers mainly include their own economic interests, external factors mainly lies in the constraints of policies and regulations, as well as consumer market awareness of the competitive pressure[24].The promotion mechanism of green building is to take the real estate developer as the center, explore its game with the government and buyers of both the innovative mechanism, to form an innovative, harmonious, green, open, sharing social benefits, economic benefits, environmental benefits of the common development of the path mechanism. 


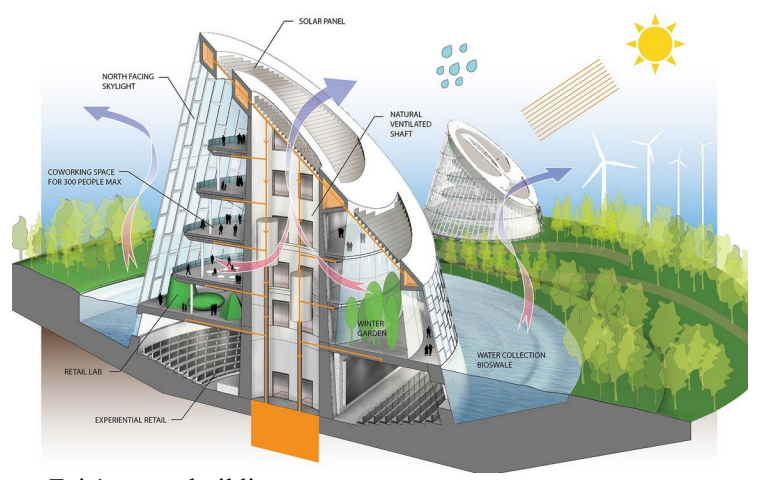

Fgi.1. green building

\section{Model establishment}

\subsection{Model hypothesis}

This paper takes the green building supply side as the breakthrough point, through the construction of the developers and buyers, government "bilateral" game to examine the green building industry chain innovation relationship[25].It is assumed that the green building's strategy choice for home buyers has two: development and non development [26,27]. Home buyers to deal with green building developers also have two behavioral strategies to choose: participate or not participate in the purchase of green building products[28]. Governments have two strategies for green building developers: the implementation of incentive policies and the implementation of policy in the form of mere formality. Therefore, the probability of green building developers to develop green buildings is $x$ and the probability of not building green buildings is $1-x$. The probability of buyers to participate in green building is $y$, buyers do not participate in the probability of green building is $1-y$. The probability for the government to implement the incentive policy is $z$, and the implementation of the policy is $1-z$. Then this paper carries out the model hypothesis with three dimensions: "economic interest", "emotional cognition" and "policy orientation".

Economic interest--Assuming that the game mod$\mathrm{el}, \lambda_{1}$ are direct revenue of green building developers, and $\lambda_{2}$ are direct revenue of green building buyers. $\varphi_{1}$ is the cost of developers to develop ordinary con- struction, and $\varphi_{2}$ is the purchase of ordinary buildings need to pay the cost of construction[29].

Emotion cognition--For more intuitive expression of the impact of consumer sentiment on the supply side, the game model is introduced to the concept of green building developers and home buyers to participate in the incremental revenue and incremental cost of green building. $\rho_{1}$ and $\rho_{2}$ are green building developers and home buyers to participate in green building incremental benefits. $\varphi_{1}^{\prime}$ is the additional cost to the development of green buildings and $\varphi_{2}^{\prime}$ is the additional cost of purchasing green buildings.

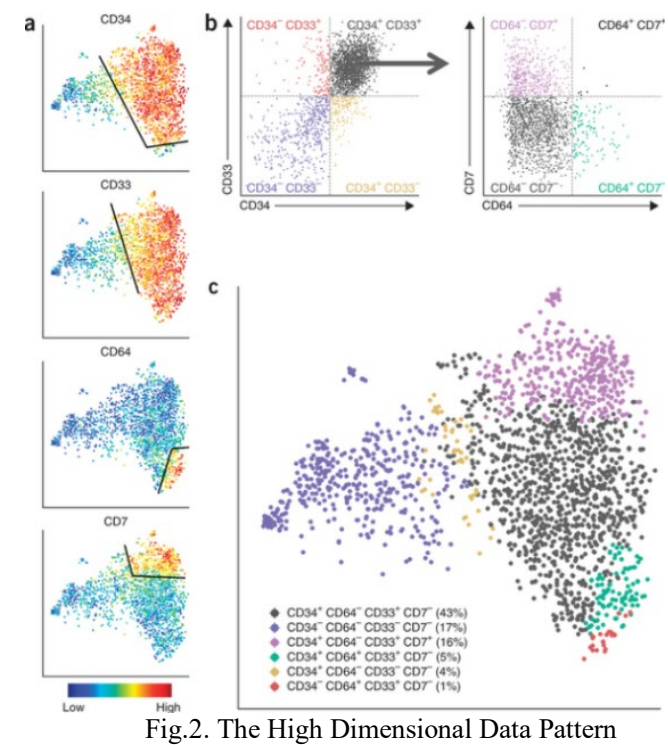

Policy Guidance-- $\lambda_{3}$ is the government social benefits from green building popularity. $-\lambda_{3}$ is the government loss because of the developer did not develop green building. When the government adopts the incentive policy, if the green building developers actively respond to the development of green build-

ing will get the government's incentive $\pi_{1}$.If green building developers still do not invest in the development of green building when the government to take incentive policies, then the government will take punitive measures $-\pi_{2}$ against green building developers.

The core participants in the supply side of green building: green building developers, home buyers 
and government. Without considering the impact of policy factors on the construction market, the game group is bounded rational, limited information role of economic man. According to the model hypothesis, the game model of developers - home buyers, developers - government is constructed. The game matrix is shown in Table 1

Table 1

the game model of the supply side of green building

\begin{tabular}{|c|c|c|c|c|c|}
\hline & & \multicolumn{2}{|l|}{ Home buyers } & \multicolumn{2}{|l|}{ Government } \\
\hline & & participate(y) & Not participate(1-y) & Incentive policy(z) & $\begin{array}{l}\text { A mere formali- } \\
\text { ty policy }(1-z)\end{array}$ \\
\hline \multirow{2}{*}{ developers } & $\begin{array}{l}\text { Development } \\
(x)\end{array}$ & $\begin{array}{l}\lambda_{1}-\varphi_{1}+\rho_{1}-\varphi_{1}^{\prime} \\
\lambda_{2}-\varphi_{2}+\rho_{2}-\varphi_{2}^{\prime}\end{array}$ & $\begin{array}{l}\lambda_{1}-\varphi_{1}-\varphi_{1}^{\prime} \\
\lambda_{2}-\varphi_{2}\end{array}$ & $\begin{array}{l}\rho_{1}-\varphi_{1}^{\prime}+\pi_{1} \\
\rho_{3}-\pi_{1}\end{array}$ & $\rho_{1}-\varphi_{1}^{\prime}$ \\
\hline & $\begin{array}{l}\text { Not develop } \\
(1-x)\end{array}$ & $-\varphi_{2}, 0$ & $\begin{array}{l}\lambda_{1}-\varphi_{1} \\
\lambda_{2}-\varphi_{2}\end{array}$ & $\begin{array}{l}-\pi_{2}, \\
-\rho_{3}+\pi_{2}\end{array}$ & 0,0 \\
\hline
\end{tabular}

Based on this, this paper takes the green building supply side of the main interests as the starting point, construct the dynamic game model of the supply side of green building, judge the relationship between the factors and factors influencing the game selection strategy, simulate dynamic evolution process of the parties, analyzes the evolution law, and puts forward the long-term coordination mechanism and decisionmaking suggestions for green building advancement.

\subsection{Green building developer - home buyers evolutionary game analysis}

In the static game of the two game groups of the green building, green building developers and home buyers average expected return are $\bar{u}_{\mathrm{s}}$ and $\bar{u} \mathrm{~g}$, respectively.

$$
\begin{aligned}
\bar{u} s= & {\left[\left(\lambda_{1}-\varphi_{1}+\rho_{1}-\varphi_{1}^{\prime}\right) y+\left(\lambda_{1}-\varphi_{1}-\varphi_{1}^{\prime}\right)(1-y)\right] x } \\
& +\left[-\varphi_{1} y+\left(\lambda_{1}-\varphi_{1}\right)(1-y)\right](1-x) \\
\bar{u}_{g}= & \left(\lambda_{2}-\varphi_{2}+\rho_{2}-\varphi_{2}^{\prime}\right) x y+\left[\left(\lambda_{2}-\varphi_{2}\right) x+\left(\lambda_{2}-\varphi_{2}\right)(1-x)\right](1-y)
\end{aligned}
$$

According to the expected return of the two game groups, green building developers can get green building strategy. The copy dynamic equation for home buyers is:

$$
\begin{aligned}
& H(x)=\frac{d x}{d t}=\left(\rho_{1} y+\lambda_{1} y-\varphi_{1}^{\prime}\right) x(1-x) \\
& H(y)=\frac{d y}{d t}=\left[\lambda_{2} x-\varphi_{2} x+\rho_{2} x-\varphi_{2}^{\prime} x-\lambda_{2}+\varphi_{2}\right) y(1-y)
\end{aligned}
$$

Make:

$$
H(x)=\frac{d x}{d t}=0 \quad H(y)=\frac{d y}{d t}=0
$$

Solving differential equations, get:

$$
\begin{aligned}
& x=0, x=1, y^{y^{*}=\frac{\varphi_{1}^{\prime}}{\rho_{1}+\lambda_{1}}} \\
& y=0, y=1, x^{*}=\frac{\lambda_{2}-\varphi_{2}}{\lambda_{2}-\varphi_{2}+\rho_{2}-\varphi_{2}^{\prime}}
\end{aligned}
$$

Based on the above calculation, the 5 partial equilibrium points of the dynamic evolutionary game matrix composed of two groups of game groups, green building developers and home buyers, are obtained:

$$
O(0,0), A(0,1), B(1,0), C(1,1), D\left(x^{*}, y^{*}\right)
$$

A series of equilibrium points are obtained by the equation group, which is the choice of the strategy of the collective set in the equilibrium state. However, not all of the equilibrium state is stable, so the stability of the equilibrium point is analyzed[30,31]. Therefore, in this paper, by using the local stability analysis method of Friedman, by (3), (4) the dynamic equation can be used to get the real estate developer - the determinant and trace of Jacobi matrix determinant and its trace. As shown below:

$\operatorname{Det}(J)=\left|\begin{array}{cc}\frac{\partial H(x)}{\partial x} & \frac{\partial H(x)}{\partial y} \\ \frac{\partial H(x)}{\partial x} & \frac{\partial H(x)}{\partial y}\end{array}\right|=(1-2 x)\left[\left(\rho_{1}+\lambda\right) y-\varphi_{1}^{\prime}\right](1-2 y)$

$\left[\left(\lambda_{2}-\varphi_{2}+\rho_{2}-\varphi_{2}^{\prime}\right) x-\left(\lambda_{2}-\varphi_{2}\right)\right]-x(1-x)\left(\rho_{1}+\lambda_{1}\right) y(1-y)\left(\lambda_{2}-\varphi_{2}+\rho_{2}-\varphi_{2}^{\prime}\right)$

$$
\begin{aligned}
& \operatorname{Tr}(J)=\frac{\partial H(x)}{\partial x}+\frac{\partial H(y)}{\partial y}=(1-2 x)\left[\left(\rho_{1}+\lambda_{1}\right) y-\varphi_{1}^{\prime}\right]+(1-2 y)\left[\left(\rho_{1}+\lambda_{1}\right) y-\varphi_{1}^{\prime}\right]+ \\
& (1-2 y)\left[\left(\lambda_{2}-\varphi_{2}+\rho_{2}-\varphi_{2}^{\prime}\right) x-\left(\lambda_{2}-\varphi_{2}\right)\right]
\end{aligned}
$$

The five equilibrium points obtained from the above deductions correspond to $\operatorname{Det}(J)$ and $\operatorname{Tr}(J)$, and the stability conditions are determined 
according to the results. The stability of the local equilibrium points is discussed respectively.Green building developers - buyers system Jacobian matrix results in Table 2 .

Table 2

Green Building Developers - Homebuyer Systems Jacobian Matrix

\begin{tabular}{|l|l|l|}
\hline equilibrium & $\operatorname{Det}(J)$ & $\operatorname{Tr}(J)$ \\
\hline$O(0,0)$ & $\varphi_{1}^{\prime}\left(\lambda_{2}-\varphi_{2}\right)$ & $-\varphi_{1}^{\prime}-\lambda_{2}-\varphi_{2}$ \\
\hline$A(0,1)$ & $\left(\rho_{1}+\lambda_{1}+\varphi_{1}^{\prime}\right)\left(\lambda_{2}-\varphi_{2}\right)$ & $\rho_{1}+\lambda_{1}-\varphi_{1}^{\prime}+\lambda_{2}-\varphi_{2}$ \\
\hline$B(1,0)$ & $-\varphi_{1}^{\prime}\left(\rho_{2}-\varphi_{2}^{\prime}\right)$ & $\varphi_{1}^{\prime}-\rho_{2}+\varphi_{2}^{\prime}$ \\
\hline$C(1,1)$ & $\left(\rho_{1}+\lambda_{1}-\varphi_{1}^{\prime}\right)\left(\rho_{2}-\varphi_{2}^{\prime}\right)$ & $-\rho_{1}-\rho_{1}+\varphi_{1}^{\prime}-\rho_{2}+\varphi_{2}^{\prime}$ \\
\hline
\end{tabular}

\begin{tabular}{|l|l|l|}
\hline$D\left(x^{*}, y^{*}\right)$ & $A^{\prime}$ & 0 \\
\hline
\end{tabular}

Real estate developers to develop green buildings on the premise that the development of ordinary buildings to ensure a certain economic benefits, so $\lambda_{1}-\varphi_{1}>0$.Similarly, home buyers to participate in green building is to meet the ordinary building guarantee income, and then in the green building and general construction of low-carbon environmental aspects of the balance, so $\lambda_{2}-\varphi_{2}>0$.Therefore, in this condition, the green building developers - buyers of local stability of the system need to discuss a total of four kinds of situations, the results of the analysis in Table 3.

Table 3

Green building developer - home buyers local stability analysis results of the system

\begin{tabular}{|c|c|c|c|c|}
\hline condition & $\begin{array}{l}\text { Equilibrium } \\
\text { point }\end{array}$ & $\begin{array}{c}\operatorname{Det}(J) \\
\text { symbol }\end{array}$ & $\begin{array}{l}\operatorname{Tr}(J) \\
\text { symbol }\end{array}$ & result \\
\hline \multirow{5}{*}{$\begin{array}{l}\rho_{1}-\varphi_{1}^{\prime}>0 \\
\rho_{2}-\varphi_{2}^{\prime}>0\end{array}$} & $O(0,0)$ & + & - & stable \\
\hline & $A(0,1)$ & + & + & Unstable \\
\hline & $B(1,0)$ & - & $+/-$ & Unstable \\
\hline & $C(1,1)$ & + & - & stable \\
\hline & $D\left(x^{*}, y^{*}\right)$ & $+/-$ & 0 & Saddle point \\
\hline \multirow{5}{*}{$\begin{array}{l}\rho_{1}-\varphi_{1}^{\prime}<0 \\
\rho_{2}-\varphi_{2}^{\prime}>0\end{array}$} & $O(0,0)$ & + & - & stable \\
\hline & $A(0,1)$ & - & $+/-$ & Unstable \\
\hline & $B(1,0)$ & - & $+/-$ & Unstable \\
\hline & $C(1,1)$ & - & $+/-$ & Unstable \\
\hline & $D\left(x^{*}, y^{*}\right)$ & $+/-$ & 0 & Saddle point \\
\hline \multirow{5}{*}{$\begin{array}{l}\rho_{1}-\varphi_{1}^{\prime}>0 \\
\rho_{2}-\varphi_{2}^{\prime}<0\end{array}$} & $O(0,0)$ & + & - & stable \\
\hline & $A(0,1)$ & + & + & Unstable \\
\hline & $B(1,0)$ & + & + & Unstable \\
\hline & $C(1,1)$ & - & $+/-$ & Unstable \\
\hline & $D\left(x^{*}, y^{*}\right)$ & $+/-$ & 0 & Saddle point \\
\hline \multirow{5}{*}{$\begin{array}{l}\rho_{1}-\varphi_{1}^{\prime}<0 \\
\rho_{2}-\varphi_{2}^{\prime}<0\end{array}$} & $O(0,0)$ & + & - & stable \\
\hline & $A(0,1)$ & - & $+/-$ & Unstable \\
\hline & $B(1,0)$ & + & + & Unstable \\
\hline & $C(1,1)$ & + & + & Unstable \\
\hline & $D\left(x^{*}, y^{*}\right)$ & $+/-$ & 0 & Saddle point \\
\hline
\end{tabular}

Conclusion 1: green building developers to develop green building incremental gains and buyers to participate in green building can get incremental benefits are positive. The probability combination ABOD of two game groups converges to (not develop, do not participate in) the strategy choice, ADBC probability combination group converges to (development, participation) strategy combination.
When $\rho_{1}-\varphi^{\prime}{ }_{1}>0, \rho_{2}-\varphi_{2}^{\prime}>0$,green building developers to develop green building and buyers to participate in green building can get positive incremental gains. Saddle point $D\left(x^{*}, y^{*}\right)$ and two unstable points $A(0,1), B(1,0)$ joined the broken line to the system is divided into two states converge in different parts. The evolutionary game system of 
the two groups has two convergent directions, namely, the strategies of convergence (not development, non-participation) or the strategy of convergence (development, participation).

Conclusion 2: Green building developers, home buyers any party into the green building transaction market incremental cost higher than its incremental revenue, through the continuous evolution of the market, the final strategic choice will be stable to the green building developers do not develop green building, home buyers do not And then the purchase of green property strategy.

When $\rho_{1}-\varphi_{1}^{\prime}<0, \rho_{2}-\varphi_{2}^{\prime}>0$, green building developers to develop green building incremental gain is negative, that the development of green building incremental cost is higher than the incremental revenue decline. When $\rho_{1}-\varphi_{1}^{\prime}>0, \rho_{2}-\varphi_{2}^{\prime}<0$, Home buyers to participate in green building incremental revenue is negative, that buyers purchase green property incremental benefit is lower than incremental costs. When $\rho_{1}-\varphi_{1}^{\prime}<0, \rho_{2}-\varphi_{2}^{\prime}<0$, both green building developers and buyers enter the green building market, both incremental costs are higher than the incremental gains of the game groups, the evolutionary game of the two game groups has only one evolutionary stabilization strategy (not development, not participation ).

\section{Green Building Developer - Government Evolutionary Game Analysis}

Traditional logistic regression using the maximum likelihood method to estimate basic model parameters, to maximize the classification accuracy of the model while however, this method ignore the data in the value of different classes, this could lead to a model in the class imbalance problem cannot very good fitting the minority class instance, leading to model generalization performance is very low in the minority class. In the following figure 5 and 6 , we show the sample logistic regression model. Because the territory asked has brought a series of questions not balanced, first is the sorter performance large scale drop, obtains the sorter has the very big deviation, the most common performance is the rare territory recognition rate is lower than the big territory by far influence to the rare territory. So long as in the rare territory existence minority noise sample as can affect this territory decision surface the study. In other words, rare territory anti-chirp ability is weak, and the sorter differentiates the rare territory sample and the noise data with difficulty.

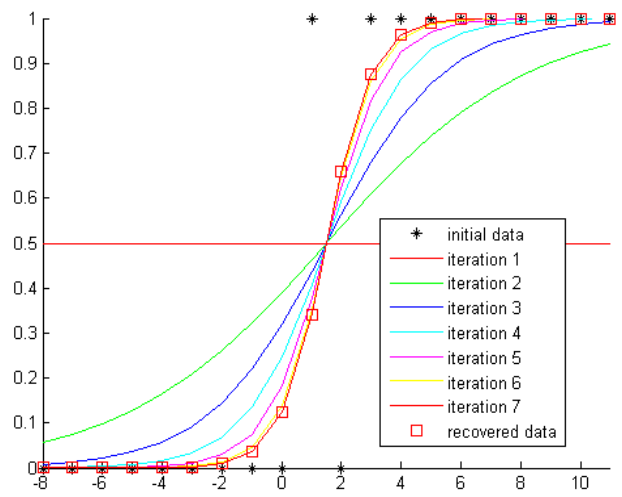

Fig.3. The Logistic Regression in the Multiple Dataset

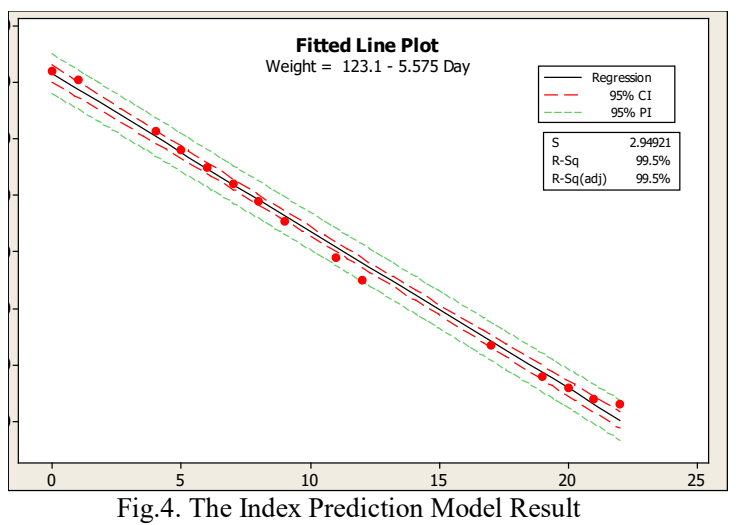

Green building developers and the government's average expected returns were $\bar{\rho} s, \bar{\rho}_{z}$. $\bar{\rho}_{s}=\left[\left(\rho_{1}-\varphi_{1}^{\prime}+\pi_{1}\right) z+\left(\rho_{1}-\varphi_{1}^{\prime}\right)(1-z)\right] x+\left(-\pi_{2} z\right)(1-x)$
$\bar{\rho}_{z}=\left[\left(\rho_{3}-\pi_{1}\right) x+\left(-\rho_{3}+\pi_{2}\right)(1-x)\right] z+\rho_{3} x(1-z)$
$G(x)=\frac{d x}{d t}=\left(\pi_{1} z+\rho_{1}-\varphi^{\prime}{ }_{1}+\pi_{2} z\right) x(1-x)$
$G(z)=\frac{d z}{d t}=\left[\left(\rho_{3} x-\pi_{1} x+\pi_{2}-\rho_{3}-\pi_{2} x\right) z(1-z)\right]$
$G(x)=\frac{d x}{d t}=0, G(z)=\frac{d z}{d t}=0 \quad$ can be obtained at the same time:

$$
\begin{aligned}
& x=0, x=1, \quad z^{*}=\frac{\varphi_{1}^{\prime}-\rho_{1}}{\pi_{1}+\pi_{2}} \\
& z=0, z=1, \quad x^{*}=\frac{\rho_{3}-\pi_{2}}{\rho_{3}-\pi_{1}-\pi_{2}}
\end{aligned}
$$

Table 4 
Results of green building developers and government systems Jacobi matrix

\begin{tabular}{|l|l|l|}
\hline $\begin{array}{l}\text { Equilibrium } \\
\text { point }\end{array}$ & $\operatorname{Det}(J)$ & $\operatorname{Tr}(J)$ \\
\hline$E_{1}(0,0)$ & $\left(\rho_{1}-\varphi_{1}^{\prime}\right)\left(\pi_{2}-\pi_{3}\right)$ & $\rho_{1}-\varphi^{\prime}+\pi_{2}-\rho_{3}$ \\
\hline$E_{2}(0,1)$ & $-\left(\rho_{1}+\varphi_{1}^{\prime}+\pi_{1}+\pi_{2}\right)\left(\pi_{2}-\rho_{3}\right)$ & $\varphi_{1}^{\prime}-\rho_{1}-\pi_{1}-\rho_{3}$ \\
\hline$E_{3}(1,0)$ & $\left(\rho_{1}-\varphi_{1}^{\prime}\right) \pi_{1}$ & $\varphi^{\prime}-\rho_{1}-\pi_{1}$ \\
\hline$E_{4}(1,1)$ & $-\left(\pi_{1}+\rho_{1}-\varphi_{1}^{\prime}+\pi_{2}\right) \pi_{1}$ & $\varphi_{1}^{\prime}-\rho_{1}-\pi_{2}$ \\
\hline$E_{5}\left(x^{*}, y^{*}\right)$ & $A$ & 0 \\
\hline
\end{tabular}

The local equilibrium point of dynamic evolutionary game matrix composed of green building developers and government:

$$
\begin{aligned}
& E_{1}(0,0), \quad E_{2}(0,1), E_{3}(1,0), \\
& E_{5}\left(\frac{\rho_{3}-\pi_{2}}{\rho_{3}-\pi_{1}-\pi_{2}}, \frac{\varphi_{1}^{\prime}-\rho_{1}}{\pi_{1}+\pi_{2}}\right)
\end{aligned}
$$

Table 5

\begin{tabular}{|c|c|c|c|c|}
\hline condition & Equilibrium point & $\operatorname{Det}(J)$ & $\operatorname{Tr}(J)$ & result \\
\hline \multirow{5}{*}{$\begin{array}{l}\rho_{1}-\varphi_{1}^{\prime}>0 \\
-\rho_{3}+\pi_{2}>0\end{array}$} & $E_{1}(0,0)$ & + & + & Un'stable \\
\hline & $E_{2}(0,1)$ & - & - & Unstable \\
\hline & $E_{3}(1,0)$ & + & - & stable \\
\hline & $E_{4}(1,1)$ & - & - & Unstable \\
\hline & $E_{5}\left(x^{*}, y^{*}\right)$ & $+/-$ & 0 & Saddle point \\
\hline \multirow{5}{*}{$\begin{array}{l}\rho_{1}-\varphi_{1}^{\prime}>0 \\
-\rho_{3}+\pi_{2}<0\end{array}$} & $E_{1}(0,0)$ & - & $+/-$ & Unstable \\
\hline & $E_{2}(0,1)$ & + & - & stable \\
\hline & $E_{3}(1,0)$ & + & - & stable \\
\hline & $E_{4}(1,1)$ & - & - & Unstable \\
\hline & $E_{5}\left(x^{*}, y^{*}\right)$ & $+/-$ & 0 & Saddle point \\
\hline \multirow{5}{*}{$\begin{array}{l}\rho_{1}-\varphi_{1}^{\prime}<0 \\
-\rho_{3}+\pi_{2}<0 \\
\quad\left(\text { if } \rho_{1}-\varphi_{1}^{\prime}<-\pi_{2} \text { ) }\right.\end{array}$} & $E_{1}(0,0)$ & + & - & stable \\
\hline & $E_{2}(0,1)$ & + & $+/-$ & Unstable \\
\hline & $E_{3}(1,0)$ & - & $+/-$ & Unstable \\
\hline & $E_{4}(1,1)$ & - & $+/-(+)$ & Unstable (stable) \\
\hline & $E_{5}\left(x^{*}, y^{*}\right)$ & $+/-$ & 0 & Saddle point \\
\hline \multirow{5}{*}{$\begin{array}{l}\rho_{1}-\varphi_{1}^{\prime}<0 \\
-\rho_{3}+\pi_{2}>0 \\
\left.{ }_{\text {(if }} \rho_{1}-\varphi_{1}^{\prime}<\pi_{2}\right)\end{array}$} & $E_{1}(0,0)$ & - & - & Unstable \\
\hline & $E_{2}(0,1)$ & + & $+/-$ & Unstable \\
\hline & $E_{3}(1,0)$ & - & $+/-$ & Unstable \\
\hline & $E_{4}(1,1)$ & - & $+/-(+)$ & Unstable (stable) \\
\hline & $E_{5}\left(x^{*}, y^{*}\right)$ & $+/-$ & 0 & Saddle point \\
\hline
\end{tabular}

Local stability analysis of green building developers and government systems
According to Eqs. (9) and (10), we obtain the Jacobian matrix determinant and the trace of the game system composed by the green building developergovernment, and obtain the Jacobian matrix determinant and traces described in the following table.

Stability of equilibrium point is discussed according to the condition of stability determination. The results of local stability analysis are shown in Table 5. In the game behavior of green building developers and government, when the government takes incentive policy, the government will adopt the strategy of substituting for the award and use a fine instead of punishment. 


\section{Construction of Green Building Evaluation System}

\subsection{Preliminary screening of evaluation index}

The analysis and study of evaluation index of green building mainly combine with the Germany DGNB sustainable building evaluation system, the British BREEAM sustainable building evaluation system and the related evaluation index in Chinese evaluation system of green building for effective analysis. To ensure the selected evaluation index has the same evaluation project which mainly involves the indoor environment quality, resource conservation and so on, and to unified define the higher similarity evaluation index contained in evaluation project as the basic evaluation index.

\subsection{Correlation determination between the indicators}

In preliminary screening of evaluation index , combine with related literature review to have effective selection, there will be a phenomenon of information overlapping between indicators. Therefore in the indicator analyzing process will have the situation of analysis complex, and the results of the analysis can not guarantee strong accuracy. However, to avoid this case, this paper mainly used principal component analysis for effective screening of evaluation index.

Based on the examples of energy utilization indexes (specific in Table 6 and Table 7), in the indexes of "renewable energy utilization" and "use of clean power" the reflected correlation coefficient are 0.785 , but the clean power belongs to renewable energy, so it can be merged into the evaluation index of renewable energy utilization. In addition, emission of carbon dioxide is one of the main indicators to effectively measure the green building, and its value is not only depends on the amount of energy utilization, but also be affected by water resource utilization and material utilization. The definition of energy utilization obviously has irrationality. Through component matrix can effectively establish indicators of energy utilization, and effectively retain the six indicators, and through this method to have corresponding analysis on the relevance judgment of other indicators. In order to ensure that the evaluation results can reach the purpose of objective and fair, to make the construction quality and the impact of environment and economy can get a more comprehensive response, the evaluation index in this paper is mainly divided into three major categories, the first one is economic quality, the second one is low carbon and resource conservation, the last one is the service quality of construction, the concrete evaluation index is shown in Table 8 .

Table 7

Component matrix of index on energy utilization

\begin{tabular}{|c|c|c|c|c|c|c|}
\hline \multirow{2}{*}{ Index } & \multicolumn{6}{|c|}{ Component } \\
\hline & 1 & 2 & 3 & 4 & 5 & 6 \\
\hline $\begin{array}{l}\text { Building } \\
\text { envelope } \\
\text { structure }\end{array}$ & .464 & -.026 & -.087 & -.609 & .499 & .218 \\
\hline $\begin{array}{l}\text { CO2 dis- } \\
\text { charge }\end{array}$ & -.270 & .216 & -.150 & .425 & .764 & .188 \\
\hline $\begin{array}{l}\text { Renewable } \\
\text { energy utili- } \\
\text { zation }\end{array}$ & .800 & -.338 & .003 & .224 & -.052 & $\begin{array}{l}- \\
.033\end{array}$ \\
\hline $\begin{array}{l}\text { Use of clean } \\
\text { power }\end{array}$ & .821 & .022 & -.551 & .575 & -.172 & .266 \\
\hline $\begin{array}{l}\text { Energy- } \\
\text { saving elec- } \\
\text { trical equip- } \\
\text { ment }\end{array}$ & .414 & .778 & .213 & -.078 & .011 & .152 \\
\hline $\begin{array}{l}\text { Large home } \\
\text { appliance } \\
\text { consumption }\end{array}$ & .174 & .866 & -.121 & -.066 & -.274 & $\begin{array}{l}- \\
.028\end{array}$ \\
\hline $\begin{array}{l}\text { Lighting } \\
\text { system }\end{array}$ & .266 & .170 & 679 & .391 & .255 & .378 \\
\hline $\begin{array}{l}\text { Air- } \\
\text { conditioning } \\
\text { system con- } \\
\text { sumption }\end{array}$ & -.552 & .023 & .540 & .140 & -.199 & .492 \\
\hline $\begin{array}{l}\text { Living hot } \\
\text { water con- } \\
\text { sumption }\end{array}$ & -.077 & -.301 & .483 & -.013 & .578 & .308 \\
\hline
\end{tabular}

Note: Valid questionnaire for 31 copies

\section{3.model building}

The current evaluation method of green building in China is usually that with the expert scoring to determine the score of each evaluation index, sum up the score of each evaluation index to get a total evaluation index score, then to define the level of evaluation index. However, this method can not fully reflect the specific difference of the content between each indicator, which makes the attached connotation of green building become fuzzier, inter evaluation indexes can not achieve the goal of coordinated development. On the basis of Table 4, this paper concretely constructed for the space model of evaluation system of green building, and has a further exploration of the evaluation results comprehensiveness of green building by this model. 
Table 6

Correlation matrix of index on energy utilization

\begin{tabular}{|c|c|c|c|c|c|}
\hline Index & $\begin{array}{l}\text { Building envelope } \\
\text { structure }\end{array}$ & $\mathrm{CO} 2$ discharge & $\begin{array}{l}\text { Renewable energy } \\
\text { utilization }\end{array}$ & Use of clean power & $\begin{array}{l}\text { Energy-saving } \\
\text { electrical equip- } \\
\text { ment }\end{array}$ \\
\hline $\begin{array}{l}\text { Building envelope } \\
\text { structure }\end{array}$ & 1.000 & -.020 & .213 & -.060 & .185 \\
\hline $\mathrm{CO} 2$ discharge & -.020 & 1.000 & -.227 & .074 & .021 \\
\hline $\begin{array}{l}\text { Renewable energy } \\
\text { utilization }\end{array}$ & .213 & -.227 & 1.000 & .785 & .089 \\
\hline Use of clean power & -.060 & .074 & .785 & 1.000 & .040 \\
\hline $\begin{array}{l}\text { Energy-saving electri- } \\
\text { cal equipment }\end{array}$ & .185 & .021 & .089 & .040 & 1.000 \\
\hline $\begin{array}{l}\text { Large home appliance } \\
\text { consumption }\end{array}$ & -.020 & -.047 & -.160 & .144 & .892 \\
\hline Lighting system & -.048 & .096 & .203 & -.100 & .252 \\
\hline $\begin{array}{l}\text { Air-conditioning } \\
\text { system consumption }\end{array}$ & -.297 & .026 & -.336 & -.225 & -.047 \\
\hline $\begin{array}{l}\text { Living hot water } \\
\text { consumption }\end{array}$ & .168 & -.221 & .419 & .022 & .100 \\
\hline Index & $\begin{array}{l}\text { Large home appliance } \\
\text { consumption }\end{array}$ & Lighting system & $\begin{array}{l}\text { Air-conditioning } \\
\text { system consumption }\end{array}$ & $\begin{array}{l}\text { Living hot water } \\
\text { consumption }\end{array}$ & \\
\hline $\begin{array}{l}\text { Building envelope } \\
\text { structure }\end{array}$ & -.020 & -.048 & -.297 & .168 & \\
\hline $\mathrm{CO} 2$ discharge & -.047 & .096 & .026 & -.221 & \\
\hline $\begin{array}{l}\text { Renewable energy } \\
\text { utilization }\end{array}$ & -.160 & .203 & -.336 & .419 & \\
\hline Use of clean power & .144 & -.100 & -.255 & .022 & \\
\hline $\begin{array}{l}\text { Energy-saving electri- } \\
\text { cal equipment }\end{array}$ & .892 & .252 & -.047 & .100 & \\
\hline $\begin{array}{l}\text { Large home appliance } \\
\text { consumption }\end{array}$ & 1.000 & .036 & -.114 & -.134 & \\
\hline Lighting system & .036 & 1.000 & .089 & .237 & \\
\hline $\begin{array}{l}\text { Air-conditioning } \\
\text { system consumption }\end{array}$ & -.114 & .089 & 1.000 & -.043 & \\
\hline $\begin{array}{l}\text { Living hot water } \\
\text { consumption }\end{array}$ & -.134 & .237 & -.043 & 1.000 & \\
\hline
\end{tabular}

Table 8

List of green building evaluation index system and related instructions

\begin{tabular}{|c|c|c|c|}
\hline First-class Index & $\begin{array}{l}\text { Second-class } \\
\text { Index }\end{array}$ & Third-class Index & Illustration \\
\hline \multirow{4}{*}{$\begin{array}{l}\text { Economic quality } \\
\text { U1 }\end{array}$} & \multirow[b]{2}{*}{ Cost U11 } & Construction cost U111 & Cost in implementation phase \\
\hline & & $\begin{array}{l}\text { Construction operation cost } \\
\text { U112 }\end{array}$ & $\begin{array}{l}\text { Maintenance fees of materials and equipment, } \\
\text { property management fees }\end{array}$ \\
\hline & \multirow[b]{2}{*}{ Benefit U12 } & Customer satisfaction U121 & Users' perception results of the house \\
\hline & & $\begin{array}{l}\text { Extra cost payback period } \\
\text { U122 }\end{array}$ & Increase cost payback period \\
\hline \multirow{7}{*}{$\begin{array}{l}\text { Low-carbon and } \\
\text { resource conser- } \\
\text { vation U2 }\end{array}$} & \multirow{6}{*}{$\begin{array}{l}\text { Energy utilization } \\
\text { U21 }\end{array}$} & $\begin{array}{l}\text { Building envelope structure } \\
\text { U211 }\end{array}$ & $\begin{array}{l}\text { Heat transfer coefficient of external wall, ground, } \\
\text { roof, external window, etc, building shape coeffi- } \\
\text { cient and other indicators }\end{array}$ \\
\hline & & $\begin{array}{l}\text { Renewable energy utilization } \\
\text { U212 }\end{array}$ & Renewable energy utilization ratio \\
\hline & & $\begin{array}{l}\text { Energy saving electrical } \\
\text { equipment U213 }\end{array}$ & $\begin{array}{l}\text { Energy-saving transformers, electrical compo- } \\
\text { nents and other utilizations }\end{array}$ \\
\hline & & Lighting system U214 & $\begin{array}{l}\text { Efficient lighting tool in public places, the use of } \\
\text { automatic energy-saving control }\end{array}$ \\
\hline & & $\begin{array}{l}\text { Energy consumption of air- } \\
\text { conditioning system U215 }\end{array}$ & $\begin{array}{l}\text { Equipment performance coefficient, energy sav- } \\
\text { ing ratio }\end{array}$ \\
\hline & & $\begin{array}{l}\text { Living hot water consump- } \\
\text { tion U216 }\end{array}$ & $\begin{array}{l}\text { Hot water system power consumption and trans- } \\
\text { mission efficiency }\end{array}$ \\
\hline & $\begin{array}{l}\text { Water resources } \\
\text { utilization } \mathrm{U} 22\end{array}$ & Less water U221 & $\begin{array}{l}\text { Water-saving appliances and water-saving } \\
\text { measures }\end{array}$ \\
\hline
\end{tabular}




\begin{tabular}{|c|c|c|c|}
\hline & & Waste water treatment U222 & $\begin{array}{l}\text { Wastewater discharge amount and processing } \\
\text { amount }\end{array}$ \\
\hline & & $\begin{array}{l}\text { Non-traditional water use } \\
\text { planning U223 }\end{array}$ & $\begin{array}{l}\text { Non-traditional use of rainwater, recycled water, } \\
\text { etc. }\end{array}$ \\
\hline & & Water saving U224 & Water resources use excess carbon emissions \\
\hline & & $\begin{array}{l}\text { Local material utilization } \\
\text { U231 }\end{array}$ & $\begin{array}{l}\text { Local materials accounted for the proportion of } \\
\text { material consumption }\end{array}$ \\
\hline & Material re- & $\begin{array}{l}\text { Use energy-saving materials } \\
\text { U232 }\end{array}$ & The proportion of energy-saving materials \\
\hline & & Environmental impact U233 & Material production carbon emissions \\
\hline & & Waste utilization U234 & Waste recovery and recycling rates \\
\hline \multirow{10}{*}{$\begin{array}{l}\text { Buildings use } \\
\text { quality U3 }\end{array}$} & \multirow{6}{*}{$\begin{array}{l}\text { Outdoor ecologi- } \\
\text { cal environment } \\
\text { U31 }\end{array}$} & Residential location U311 & $\begin{array}{l}\text { The content of harmful substances in the soil, the } \\
\text { original river, wetland }\end{array}$ \\
\hline & & Infrastructure U312 & Facilities, barrier free facilities \\
\hline & & Virescence U313 & Green space ratio \\
\hline & & Traffic condition U314 & $\begin{array}{l}\text { Underground garage proportion, public accessibil- } \\
\text { ity }\end{array}$ \\
\hline & & Noise abatement U315 & $\begin{array}{l}\text { Noise sound pressure and noise reduction } \\
\text { measures }\end{array}$ \\
\hline & & Microclimate U316 & $\begin{array}{l}\text { Settlements humidity, harmful content and meas- } \\
\text { uring ratio of external settlements }\end{array}$ \\
\hline & \multirow{2}{*}{$\begin{array}{l}\text { Indoor environ- } \\
\text { mental quality } \\
\text { U32 }\end{array}$} & $\begin{array}{l}\text { Indoor environmental quality } \\
\text { U321 }\end{array}$ & $\begin{array}{l}\text { Air quality, light environment, acoustic environ- } \\
\text { ment, thermal environment }\end{array}$ \\
\hline & & Moistureproof quality U322 & Rain and snow weather indoor humidity \\
\hline & \multirow{2}{*}{$\begin{array}{l}\text { Operation man- } \\
\text { agement U33 }\end{array}$} & Garbage disposal U331 & Garbage classification and flow control \\
\hline & & Residential security U332 & Intelligent systems, unit area and security number \\
\hline
\end{tabular}

- Emotional cognition: Green building supply

\section{Countermeasures and Suggestions}

Based on the green building developers and the supply side "bilateral evolutionary game" analysis, combined with the "economic interests" and "emotion" and "policy oriented" three major constraints on green building dynamic game model based on promoting mechanism put forward countermeasures three aspects of suggestions:

- Economic interests: Green building supply side should integrate green building upstream and downstream industry chain. Mature industrial chain contributes to the formation of scale benefits green building industry. Through the scale effect, improve incremental income, reduce incremental costs. After the accumulation of advanced technology digestion understanding, can increase the incremental economic benefits of green building. At the same time, the domestic and international green building new technology actively introduce, promote, adopt subsidies, incentives and other incentive policy, for green building developers to reduce investment development design green building incremental cost. side should strengthen the green building products marketing planning. When the incremental benefits of both sides of the game groups are greater than incremental costs, it is very important for green building investment to develop green buildings and buyers involved in the purchase of the probability combination. Home buyers to participate in the higher the degree of green building, green construction enterprises to invest in the development of green building accounts will increase, promote the promotion of green building market development

- Policy orientation: Green building supply side should establish feasible and effective green building supervision system. Perfecting the legal system and strengthen supervision, especially the increase of the development of green building, green building, fake fake shoddy behavior severely ruling. At the same time, should also encourage green building technology independent research and innovation. In the green building technology development stage, economic benefits are not significant, developers will face greater financial pressure is difficult to maintain, through policy, subsidies and other ways to help develop- 
ers solve the technical problems of green building

\section{Conclusions}

Green building is an important carrier to achieve sustainable development of the construction industry, and exploring the relationship between stakeholders is a problem worthy of attention and research in the sustainable development of the construction industry. This paper from the perspective of supply side reform of green building developers -- buyers from three dimensions of economic interests, emotion cognition and policy orientation is established, two groups of developers -- model of government supply side dynamic evolution game, the stability of evolutionary equilibrium evolution strategies are analyzed and discussed.

In the dynamic game developers - buyers, the incremental cost of the supply side of any party to the transaction market is higher than the incremental revenue, promoting mechanism will fail; convergence direction of incremental profit of green building developers on the supply side of the development of random. If the green building developers and property buyers the incremental cost of any party involved in green building trades than the incremental income, after the evolution of the market, the final choice of strategy will stabilize to green building developers does not invest in the development of green building, buyers choose not to purchase green building strategies. If the two party participation in green building transactions are profitable, the incremental income is greater than the incremental cost, then the model will provide two different strategies (development, participation), (no, not to participate in the development of evolution). Under this condition, the initial game green building investment development green building and property buyers involved in the purchase of the probability combination is particularly important.

In the dynamic game of the developer government, the initial incentive measures for supply side have guiding effect on green building. The incentive reward the government to adopt green building developers did not become the important factors affecting the promotion of green building in the evolutionary game, the incremental cost and development of green building is a key factor in promoting the green building. Secondly, the incremental profit developers invest in the development of green building green building is positive, the government to take regulatory punitive measures the extent to which directly affect the final results of both sides of the game evolution; third, incremental profit developers invest in the development of green building green building is negative, the government even draconian penalties may not be able to correctly guide the green developers investment and development of green building. Finally, if developers invest in the development of green building green building incremental profit is negative, the government guarantee of green building green building development enterprises not punished the loss is higher than that in the government does not take the incentive policy of green building enterprise development green building loss loss, to a large extent, choose the development of green building green building developers guide strategy.

Based on the green building developers and the supply side "bilateral evolutionary game" analysis, combined with the "economic interests" and "emotion" and "policy oriented" three constraints, put forward the green building green building supply side should integrate upstream and downstream industry chain; strengthen the marketing planning of green building products; the establishment of feasible and effective the supervision system and the development of green building energy consumption tax, environmental tax and other measures.

\section{Acknowledgment}

This paper is funded by National Scientific Fund(No. 51108185 and No. 51778235), Province natural science fund of Guangdong(No. 2016A030313513), State Key Laboratory of Subtropical Building Science(No. 2013KB24), Guangzhou development and reform commission energy-saving special fund project (Technology research of regional energy based on the energy cascade utilization), Basic scientific research fund of South China University of Technology(No. 2015ZM013) and fund of Guangdong modern architectural creation and engineering technology research centre (No.2016AZ28).

\section{References}

[1] Duan, W., Yang, S. (2013). Service cost sharing contract incentive mechanism based on telecom business agent. System engineering, 1, 92-97. 
[2] Gao, L. (2016). Welcome the wind blowing development sail, take the road of innovation, skill machine supply side reform, Tile world, 04,9-14.

[3] Jin, Z., Sun, J. (2010). Based on Externality Analysis of green building economic incentive policy design. Construction science, 26, 57-62.

[4] Kai, Y., Wan, Y. (2011). Comparison of the internationalization of China green building incentive policy performance. Housing industry, 4, 30-31.

[5] Ma, G., Hu, H., Wang, H. (2007). Research on green building development and comprehensive evaluation operation mechanism. Building economy, 3, 36-38.

[6] Pereira, C., Ferreira, C. (2015). Identification of IT Value Management Practices and Resources in COBIT 5. RISTIRevista Ibérica de Sistemas e Tecnologias de Informação, (15), 17-33.

[7] Sun, P., Jin, G. (2006). Research on external economy and compensation of green technology development. Scientific management research, 24, 32-36.

[8] Tu, J., Ge, H. (2009). Game Analysis in the interests of energy saving buildings government real estate developers. Journal of West Anhui University, 02, 113-115.

[9] Hwang, B.G., Shan, M. and Phuah, S.L., 2017. Safety in green building construction projects in Singapore: Performance, critical issues, and improvement solutions. KSCE Journal of Civil Engineering, pp.1-12.

[10]Akcin, M., Kaygusuz, A., Karabiber, A., Alagoz, S., Alagoz, B.B. and Keles, C., 2016, April. Opportunities for energy efficiency in smart cities. In Smart Grid Congress and Fair (ICSG), 2016 4th International Istanbul (pp. 1-5). IEEE.

[11] Subagdja, B. and Tan, A.H., 2016. Interactive teachable cognitive agents: Smart building blocks for multiagent systems. IEEE Transactions on Systems, Man, and Cybernetics: Systems, 46(12), pp.1724-1735.

[12]Nag, S., Kundu, S., Sinha, D., RoyChowdhury, S., Mukherjee, P., Goswami, U. and Ganguly, R., 2016, October. A comparative-techno economic feasibility study between roof-top and building integrated photovoltaic technology for development of green campus. In Ubiquitous Computing, Electronics \& Mobile Communication Conference (UEMCON), IEEE Annual (pp. 1-6). IEEE.

[13] Vyas, G.S. and Jha, K.N., 2017. Benchmarking green building attributes to achieve cost effectiveness using a data envelopment analysis. Sustainable Cities and Society, 28, pp.127-134.

[14] Asadullah, M. and Celik, A.R., 2016. An Effective Approach to Build Smart Building Based on Internet of Things (IoT). Journal of Basic and Applied Scientific Research (JBASR), 6(5), pp.56-62.

[15]Zuo, J., Pullen, S., Rameezdeen, R., Bennetts, H., Wang, Y. Mao, G., Zhou, Z., Du, H. and Duan, H., 2017. Green building evaluation from a life-cycle perspective in Australia: A critical review. Renewable and Sustainable Energy Reviews, 70, pp.358-368

[16] MacNaughton, P., Spengler, J., Vallarino, J., Santanam, S., Satish, U. and Allen, J., 2016. Environmental perceptions and health before and after relocation to a green building. Building and environment, 104, pp.138-144.
[17]Jones, L., Jones, L., Wong, W. and Wong, W., 2016. More than just a green building: Developing green strategies at the Chinese University of Hong Kong Library. Library Management, 37(6/7), pp.373-384.

[18] Tam, V.W., Senaratne, S., Le, K.N., Shen, L.Y., Perica, J. and Illankoon, I.C.S., 2017. Life-cycle cost analysis of greenbuilding implementation using timber applications. Journal of Cleaner Production, 147, pp.458-469.

[19] Grabowski, M., Kochanneck, S., Mauser, I., Henning, H.M and Schmeck, H., 2016. Using VOC Sensors and the Internet of Things to Improve the Energy Efficiency in Smart Buildings. In VDE Kongress.

[20] Smith J C, Krishnan M, Petridis L, et al. Structure and Dynamics of Biological Systems: Integration of Neutron Scattering with Computer Simulation[J]. Office of Scientific \& Technical Information Technical Reports, 2012:189-204.

[21] Azadeh A, Faiz Z S, Asadzadeh S M, et al. An integrated artificial neural network-computer simulation for optimization of complex tandem queue systems.[J]. Mathematics \& Computers in Simulation, 2012, 82(4):666-678.

[22]Kim T H, Park S E. A Study on Computer Simulation to Investigate Correlations between Temperature Controlling Effect of Green Roof System and the Photovoltaic Power Generation Efficiency[J]. 2013, 33(4):70-79.

[23] Trani A A, Gu X, Lu B, et al. Integrated Computer Simulation Model for the Development of China's Air Transportation System $[\mathrm{C}] / /$ Transportation Congress, Volumes 1 and 2@sCivil Engineers-Key to the World's Infrastructure. ASCE, 2015:75-85.

[24] Mittal S, Ruth M, Pratt A, et al. A system-of-systems approach for integrated energy systems modeling and simulation[C]// Conference on Summer Computer Simulation. Society for Computer Simulation International, 2015:1-10.

[25] Łukasz Wardziak, Jaworski M. Computer simulations of heat transfer in a building integrated heat storage unit made of PCM composite $[\mathrm{J}]$. Thermal Science \& Engineering Progress, 2017, 2:109-118.

[26] Su C L, Weng R H. Voltage Quality Study of Integrated Power System for All-Electric Vessels Using Dynamic Simulation Techniques[J]. Advanced Materials Research, 2012, 433440:2546-2550

[27]Hsieh, T. T., Lai, K. P., Chiang, C. M., \& Ho, M. C. (2013) Eco-efficiency model for green building material in a subtropical climate. Environmental Engineering Science, 30(9), 555572.

[28]Rhoads, W. J., Pearce, A., Pruden, A., \& Edwards, M. A. (2015). Anticipating the effects of green buildings on water quality and infrastructure. Journal American Water Works Association, 107(4), 50-61.

[29]ChaudharyTariq, \& PirachaAwais. (2013). Effective contribution of structural engineers to green buildings and. Canadian Journal of Civil Engineering, 40(1), 97-100.

[30]Challener, C. (2013). Paints and coatings in step with the green building movement. Jct Coatings Tech, 10(8), 20-28.

[31]Lim, W. F., Chew, K. C., Yang, P. K. L., Seng, K. T., Ho, N. Y., \& Low, G. L. (2015). Evaluation of rca concrete for the construction of samwoh eco-green building. Magazine of Concrete Research, 67(12), 633-644. 